\title{
DESCRIPTIVE AND LOGISTIC REGRESSION APPROACHES FOR ANALYZING THE FACTORS AFFECTING THE ADOPTION OF COCOA AGROFORESTS BY FARMERS IN THE CENTRE REGION OF CAMEROON
}

\author{
Achille Jean Jaza Folefack \\ Department of Agricultural Economics, University of Dschang, Cameroon \\ E-mail: ajazafol@yahoo.fr
}

\begin{abstract}
After the 1990s drop of cocoa prices in the world market accompanied by liberalization in this sector, farmers in the Centre region of Cameroon were advised to supplement their revenue by shifting from the mono-crop of cocoa to the cultivation of cocoa agroforest. But until now, this practice is still timidly adopted by cocoa producers. This paper analyses the factors determining the adoption of cocoa agroforest by using both the descriptive statistics and logit model from data collected from 128 farmers residing in this area. The results reveal that, farmers adopting that technique are mostly young, male, member of peasant association, member in rural credit system, frequently in contact with extension agents, educated, land renters, employers of salarial labour, occupant of managerial position, with large household size, with previous practice of crops' association or rotation and with low cocoa yield during the previous years. However, the likelihood is low to adopt the cocoa agroforest for those old farmers, owners of large land area, and with old cocoa orchards. The study therefore recommends to the government to popularize the cocoa agroforest by reviewing these disfavourable factors and by rewarding/subsidizing farmers planting supplementary trees within their cocoa orchards.
\end{abstract}

\section{KEY WORDS}

Adopter, agroforest, cocoa, logit model, odds ratio.

Cameroon, like most of the developing countries, depends heavily on agriculture which contributes to about $22 \%$ of Gross Domestic Product (GDP) and employs $70 \%$ of its population. After the country's independence in 1960, the government granted subsidy to support the producers of the main cash crops (cocoa, coffee, etc) (Ministry of Agriculture, 2015). However, with the economic crisis of the early 1990s, the State was obliged to disengage from all sectors and took particular measures for cocoa producers (removal of subsidy for credit, fertilizers, pesticides, seeds, etc) in order to restrict the public expenditures and boost the country's economy. In this respect, the liberalization of the marketing of cocoa and coffee products was the major measure adopted under the structural adjustment program of International Monetary Fund (IMF) and World Bank (WB).

That liberalization accompanied by the dissolution of the former National Product Marketing Board (NPMB) in charge of price stabilization of cocoa and coffee, the decline of prices of cocoa in the world market led to a sudden drop of the incomes of cocoa producers at that period, thereby increasing poverty in the traditional cocoa production zone of the Centre region (Jagoret et al., 2006; Degrande et al., 2007).

The most important measure of farmers' adaptation to that situation was the diversification of their products and namely, the intensification of the diversification of trees' species grown inside their cocoa orchards. This consists to preserve many domestic fruit trees' species such as safout, ndjansang and bush mango which grow spontaneously in the cocoa plantation or are planted by the farmer.

In short, in order to overcome the major difficulties faced by the farmers (cocoa's price instability, removal of inputs' subsidy, lack of credit facilities, etc), some innovative strategies which include the rational management of forest resources found in this region were developed so as to improve the living conditions of the rural population and while protecting the environment. Among these strategies, the program of domestication of local fruit trees and medicinal species was launched in 1996 in the Centre region under the funding and 
supervision of the ICRAF/WAC ${ }^{1}$. This program sensitizes most farmers of this region to acquire tree domestication skills and namely to diversify their cocoa plantations with several species of domestic fruit trees such as safout, ndjansang, bush mango, etc. However in spite of this sensitization, most farmers are not yet convinced on the profitability of implementing the cocoa agroforests (i.e. cocoa planted in association with several species of domestic fruit trees), rather than growing the cocoa in mono-crop. These farmers ignore that, preserving the domestic fruit trees' within the cocoa orchard could protect cocoa from sunshine because the cocoa trees grown in direct sunlight without the protection of shade can suffer from heat stress (Jagoret et al., 2006; Degrande et al., 2007).

Nowadays, the adoption rate of cocoa agroforests is still timid in the Centre region since only $29 \%$ of farmers have currently opted to produce cocoa in association with other domestic fruit trees (Ministry of Agriculture, 2015). The remaining $71 \%$ of farmers from this zone are still reticent or doubt on the efficacy, productivity or profitability of improving their incomes by adopting the cocoa agroforests. This latter group rather prefer to cultivate the cocoa in monocrop because they think it is less costly, less labour demanding, and easier to manage than planting the cocoa in association with domestic fruit trees which they believe as expensive and time consuming for maintenance.

Most recent studies (Todem, 2005; Eboutou, 2010; Jaza et al., 2015) have focused on evaluating the financial and economic gain of cocoa agroforests (in comparison to cocoa cultivated in mono-crop), but none of them analyzes the reasons of the low rate of adoption of the cocoa agroforests by farmers in the Centre region. Hence, this paper covers this gap by analyzing the determinants of agroforests' adoption by the cocoa producers of this zone.

\section{MATERIALS AND METHODS}

Study area and data collection. The study was conducted by using the data collected from May to October 2015 in five randomly selected zones (Bafia, Monatele, Mfou, Eseka and Mbalmayo) in the cocoa producing basin of the Centre region of Cameroon. This area was chosen because cocoa is the main cash crop occupying $90 \%$ of farmers and it is a zone where cocoa yield is declining (because of the old age of cocoa orchards and farmers), thus needing new strategies to increase its productivity and the farmer's income.

Apart from cocoa $(C)$ production, the Centre region is by nature a forestry zone where the domestic fruit trees' species such as safout (S), ndjansang $(\mathrm{N})$, bush mango (M), etc spontaneously grow themselves or are planted by farmers so as to form the cocoa agroforests $^{2}$ of: $[\mathrm{C}+\mathrm{S}],[\mathrm{C}+\mathrm{M}],[\mathrm{C}+\mathrm{N}],[\mathrm{C}+\mathrm{S}+\mathrm{M}],[\mathrm{C}+\mathrm{S}+\mathrm{N}],[\mathrm{C}+\mathrm{M}+\mathrm{N}],[\mathrm{C}+\mathrm{S}+\mathrm{M}+\mathrm{N}]$ (Jaza et al., 2015). These reasons motivated ICRAFMAC to choose the region in 1996 for launching its program of domesticated trees' species incorporated within the cocoa plantations. Hence, in order to benefit from the available facilities and database of that program, the same area was chosen for this study.

A total of 128 farmers comprised of 62 adopters and 66 non-adopters of cocoa agroforests residing in that region were purposely selected for the survey. The non-adopters of cocoa agroforests were farmers producing cocoa in mono-crop whereas the adopters of this practice were those producing cocoa in association to other domestic fruit trees. Using a prepared questionnaire and interview schedule, cross-sectional primary data of the cropping season 2014/2015 were collected from the two categories of farmers (adopters and nonadopters of cocoa agroforests).

The data collected from each farmer were precisely the: age, gender, farm size/land area cultivated, membership in a peasant's association, membership in a rural credit system, frequency of contact with extension agents, level of education, ownership of land property right, use of salarial labour, previous practice of crops' association or rotation, occupation of

\footnotetext{
${ }^{1}$ ICRAF=International Centre for Research in Agroforestry; WAC=World Agroforestry Centre.

${ }^{2} \mathrm{C}=$ Cocoa; $\mathrm{S}=$ Safout; $N=$ Ndjansang; $M=$ Mango.
} 
managerial position, size of household, age of cocoa orchard, cocoa yield during previous years, etc.

Data analysis. In this study, in order to analyze the factors affecting the adoption of cocoa agroforests by farmers, the logit model is more convenient because the dependant variable is qualitative in nature, the explanatory variables are a mix of continuous and qualitative variables, and the sample size is low ( $N=128)$ (Gujarati, 1995; Terrell, 1999; Wooldridge, 2009).

The logit model is used to predict the logit of the probability of the occurrence of the event, that is, the natural log of the odds ratio of having made one or the other decision (adoption or non-adoption of cocoa agroforests by farmers). By denoting $\mathrm{P}$ as the probability of making such decision from the predictors ${ }^{3} X_{1}$ to $X_{14}$, the mathematical formulation of the logit model used in this study is expressed in equation (1) such as:

$$
Y=\operatorname{Logit}(P)=\operatorname{Ln}\left(\frac{P}{1-P}\right)=\alpha+\beta_{1} X_{1}+\beta_{2} X_{2}+\ldots \ldots \ldots \ldots \ldots+\beta_{14} X_{14}
$$

where: $P$ : is the predicted probability of the occurrence of event (adoption of cocoa agroforests); 1-P: is the predicted probability of non-occurrence of event (non-adoption of cocoa agroforests); Y: Farmer group (coded as 1= adopters of cocoa agroforests, $0=$ nonadopters of cocoa agroforests); $X_{1}$ : Age of farmer (in years); $X_{2}$ : Gender of farmer (coded as $1=$ male, $0=$ female); $X_{3}$ : Farm size/land area cultivated by the farmer (in ha); $X_{4}$ : Farmer's membership in a peasant's association (coded as $1=y e s, 0=n o$ ); $X_{5}$ : Farmer's membership in a rural credit system (coded as $1=y e s, 0=n o$ ); $X_{6}$ : Frequency of contact with extension agents (per cropping year); $X_{7}$ : Farmer's education (coded as $1=$ educated, $0=$ non-educated/illiterate);

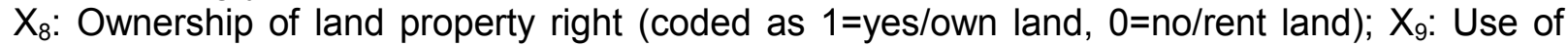
salarial labour (coded as $1=y e s, 0=n o$ ); $X_{10}$ : Previous practice of crops' rotation or association (coded as $1=y e s, 0=n o$ ); $X_{11}$ : Occupation of managerial position (coded as $1=y e s, 0=n o$ ); $X_{12}$ : Size of the farmer's household (in number of persons); $X_{13}$ : Age of cocoa orchard (in years); $\mathrm{X}_{14}$ : Cocoa yield during previous years (in $\mathrm{t} / \mathrm{ha}$ ).

This study uses the SPSS software program (version 21.0) in order to estimate the coefficients from equation (1) such as: $\beta_{1}, \beta_{2}, \ldots \ldots, \beta_{14}$ (termed as $\beta_{k}$ ) which are respectively the slope coefficients of the explanatory variables $X_{1}, X_{2}, \ldots \ldots, X_{14}$ (termed as $X_{k}$ ); and $\alpha$ : Intercept term.

The exponentials of the slope coefficients $\beta_{k}$ associated to the explanatory variables are interpreted as the Odds Ratio (OR) of the occurrence of the event ${ }^{4}$ (adopting the cocoa agroforests) for each increase in the predictor. A positive $\beta_{k}$ coefficient generally displays an OR greater than one $(O R>1)$ whereas a negative $\beta_{k}$ coefficients usually indicates an OR lower than one $(O R<1)$ (Gujarati, 1995; Terrell, 1999; Wooldridge, 2009).

\section{RESULTS AND DISCUSSIONS}

Descriptive field survey results. The factors affecting the adoption of cocoa agroforests by farmers in the Centre region are described in Table 1. They are differently interpreted depending whether the farmers' responses are discrete or continuous in nature.

The factors with continuous responses are the: age of farmer, farm size, frequency of contact with extension agents, size of farmer's household, age of cocoa orchard, cocoa yield during the previous years (Table 1). By considering the age of farmers (Table 1), the results for the selected people indicate an average age of 46.2 years and a standard deviation of 8.13 years. The youngest farmer is 21 years old whereas the most-aged farmer is 78 years old. The quite distant standard deviation (8.13 years) from the computed mean (46.2 years) implies that, the age of most farmers is $46.2 \pm 8.13$ years (38.07 sage $\leq 54.33$ ). Similar interpretations can be done for the rest of continuous variables (Table 1).

\footnotetext{
${ }^{3}$ Explanatory variables $=$ Predictors in logit model=Factors affecting the adoption of cocoa agroforests by farmers. ${ }^{4}$ Odds $=$ Number of cases the event occurs, divided by the number of cases in which the event does not occur. Hence, the odds in this paper are interpreted as the chance of adopting the cocoa agroforests.
} 
Table 1 - Descriptive responses of factors affecting the adoption of cocoa agroforests by farmers in the Centre region $(\mathrm{N}=128)$

\begin{tabular}{lcccc}
\hline \multicolumn{1}{c}{ Factor/variable } & Min. & Max. & Mean & Standard Deviation \\
\hline Farmer group (1/0) & 0 & 1 & 0.35 & 0.21 \\
Age of farmer (years) & 21 & 78 & 46.2 & 8.13 \\
Gender of farmer (1/0) & 0 & 1 & 0.57 & 0.45 \\
Farm size/land area cultivated by the farmer (ha) & 0.04 & 0.8 & 0.29 & 0.21 \\
Farmer's membership in a peasant association (1/0) & 0 & 1 & 0.52 & 0.43 \\
Farmer's membership in a rural credit system (1/0) & 0 & 1 & 0.61 & 0.49 \\
Frequency of contact with extension agents (per year) & 0 & 6 & 3.10 & 2.06 \\
Level of education of farmers (1/0) & 0 & 1 & 0.52 & 0.09 \\
Ownership of land property right (1/0) & 0 & 1 & 0.42 & 0.43 \\
Use of salarial labour (1/0) & 0 & 1 & 0.53 & 0.36 \\
Previous practice of crops association or rotation (1/0) & 0 & 1 & 0.57 & 0.25 \\
Occupation of managerial position (1/0) & 0 & 1 & 0.54 & 0.27 \\
Size of the farmer's household (number of persons) & 1 & 25 & 9.13 & 2.14 \\
Age of cocoa orchard (years) & 20 & 34 & 26.1 & 3.92 \\
Cocoa yield during previous years (t/ha) & 0.2 & 0.4 & 0.34 & 0.12 \\
\hline
\end{tabular}

Figures in parentheses represent either the units of measurement for continuous variables or the codes of discrete variables as defined in equation (1). For example, the farmer group (1/0) indicates that: 1=adopter and $0=n o n-$ adopter of cocoa agroforests, and so on.

Table 2 - Frequency and adoption rate of cocoa agroforests by considering the category of response from each variable $(\mathrm{N}=128)$

\begin{tabular}{|c|c|c|c|c|c|}
\hline \multirow{2}{*}{ Factor/variable } & \multirow{2}{*}{ Category of response } & \multirow{2}{*}{$\begin{array}{l}\text { Total number } \\
\text { of farmers } \\
\text { interviewed in } \\
\text { category (N') }\end{array}$} & \multirow{2}{*}{$\begin{array}{c}\text { Counted } \\
\text { number of } \\
\text { adopters: } \\
\text { Frequency(f) }\end{array}$} & \multicolumn{2}{|c|}{$\begin{array}{l}\text { Adoption rate of cocoa } \\
\text { agroforests (\%) }\end{array}$} \\
\hline & & & & $\begin{array}{c}\text { Within } \\
\text { category }\end{array}$ & $\begin{array}{l}\text { From all } \\
\text { farmers }\end{array}$ \\
\hline \multirow{2}{*}{ Age of farmer } & $>45$ years $($ old $)$ & 91 & 25 & 27.47 & 19.53 \\
\hline & $\leq 45$ years (young) & 37 & 29 & 78.38 & 22.66 \\
\hline \multirow{2}{*}{ Gender of farmer } & Male & 77 & 62 & 80.52 & 48.44 \\
\hline & Female & 51 & 18 & 35.29 & 14.06 \\
\hline \multirow{2}{*}{$\begin{array}{l}\text { Farm size/land area } \\
\text { cultivated by farmer }\end{array}$} & $>0.45$ ha (large) & 31 & 08 & 25.81 & 06.25 \\
\hline & $\leq 0.45 \mathrm{ha}$ (small) & 97 & 78 & 80.41 & 60.94 \\
\hline \multirow{2}{*}{$\begin{array}{l}\text { Farmer's membership to } \\
\text { peasant association }\end{array}$} & Yes & 49 & 43 & 87.76 & 33.59 \\
\hline & No & 79 & 11 & 13.92 & 08.59 \\
\hline \multirow{2}{*}{$\begin{array}{l}\text { Farmer's membership to } \\
\text { rural credit system }\end{array}$} & Yes & 53 & 50 & 94.34 & 39.06 \\
\hline & No & 75 & 09 & 12.00 & 07.03 \\
\hline \multirow{2}{*}{$\begin{array}{l}\text { Frequency of contact with } \\
\text { extension agents }\end{array}$} & $>6$ per year (high) & 27 & 25 & 92.59 & 19.53 \\
\hline & $\leq 6$ per year (low) & 101 & 18 & 17.82 & 14.06 \\
\hline \multirow{2}{*}{ Farmer's education } & Educated & 33 & 28 & 84.85 & 21.88 \\
\hline & Non-educated & 95 & 16 & 16.84 & 12.50 \\
\hline \multirow{2}{*}{$\begin{array}{l}\text { Ownership of land property } \\
\text { right }\end{array}$} & Yes (owned land) & 68 & 21 & 30.88 & 16.41 \\
\hline & No (rented land) & 60 & 56 & 93.33 & 43.75 \\
\hline \multirow{2}{*}{ Use of salarial labour } & Yes & 57 & 53 & 92.98 & 41.41 \\
\hline & No & 71 & 26 & 36.62 & 20.31 \\
\hline \multirow{2}{*}{$\begin{array}{l}\text { Previous practice crops' } \\
\text { association/rotation }\end{array}$} & Yes & 81 & 59 & 72.84 & 46.09 \\
\hline & No & 47 & 11 & 23.40 & 08.59 \\
\hline \multirow{2}{*}{$\begin{array}{l}\text { Occupation of managerial } \\
\text { position }\end{array}$} & Yes & 75 & 67 & 89.33 & 52.34 \\
\hline & No & 53 & 13 & 24.53 & 10.16 \\
\hline \multirow{2}{*}{ Size of farmer's household } & $>10$ persons (large) & 32 & 28 & 87.50 & 21.88 \\
\hline & $\leq 10$ persons (small) & 96 & 13 & 13.54 & 10.16 \\
\hline \multirow{2}{*}{ Age of cocoa orchard } & $>20$ years $($ old $)$ & 105 & 07 & 06.67 & 05.47 \\
\hline & $\leq 20$ years (young) & 23 & 21 & 91.30 & 16.41 \\
\hline \multirow{2}{*}{$\begin{array}{l}\text { Cocoa yield during previous } \\
\text { years }\end{array}$} & $>0.3 \mathrm{t} / \mathrm{ha}$ (high) & 16 & 02 & 12.50 & 01.56 \\
\hline & $\leq 0.3 \mathrm{t} / \mathrm{ha}(\mathrm{low})$ & 112 & 105 & 93.75 & 82.03 \\
\hline
\end{tabular}

(i)-The counted number of adopters is the observed frequency (f) of response out of (or over) the total number of farmers interviewed within the category; (ii)-The adoption rate A' of cocoa agroforets within the given category of any variable is computed by using the following formula: $A^{\prime}=\left(f^{*} 100\right) / N^{\prime}$ where: $f$ is the frequency of adopter within the category or sub-variable; $N$ ' is the total number of farmers who gave that response (or which were interviewed) in the category; (iii)-The adoption rate $A$ of cocoa agroforests with respect to all farmers is computed by using the following formula: $A=\left(f^{\star} 100\right) / N$ where: $f$ is the frequency of adopter within the category or sub-variable; $N$ is the total number of farmers with $N=128$ for all farmers. 
The factors with discrete responses in Table 1 are the: gender of farmer, farmer's membership in a peasant's association, farmer's membership in a rural credit system, level of education of farmer, ownership of land property right, use of salarial labour, previous practice of crops' association or rotation, and occupation of managerial position. The computed mean is 0.57 for the gender of farmer (coded as $1=$ male, $0=$ female); hence, more than half of selected farmers are male. The large standard deviation (0.45) implies that most observed values range between $0.57 \pm 0.45(0.12 \leq$ gender $\leq 1.02)$, confirming that the selected farmers are either male or female. The interpretations are similar for all the other qualitative variables (Table 1).

Table 2 presents the counted number of adopters and adoption rate of cocoa agroforests for each variable. This enables us to see the factors which influence the most the agroforest practices in the study area. Taking the gender of farmer for example, the computed adoption rate for this factor indicates that, male farmers tend to adopt the most the cocoa agroforests as compared to female farmers. Out of 77 surveyed male farmers, a proportion of $80.52 \%$ (that is, a frequency of 62 ) are adopters of cocoa agroforests whereas $35.29 \%$ from the 51 surveyed female farmers use this practice. In total from all the 128 selected farmers, a proportion of $48.44 \%$ of male are adopters of cocoa agroforests as compared to only $14.06 \%$ for the female gender (Table 2). Similarly, the percentage of adoption of cocoa agroforests is higher for young farmers, member of peasant's association, member in rural credit system, users of salarial labour, farmers more frequently in contact with extension agents, educated people, who previously practice crops' association or rotation, and occupants of managerial position (Table 2). In opposite, the percentage of adoption of cocoa agroforests is lower for farmers with large farm size (cultivated land area), land owners, who own small household size, with cocoa orchard of old age and who recorded high cocoa yield during the previous years (Table 2).

Econometrics analysis from the logit model results. Table 3 shows the logit model results for analyzing the factors influencing the cocoa agroforests' adoption by farmers in the study area. The overall goodness-of-fit measured by the significance of the Chi-Square statistic in the Omnibus test of model coefficients is high $\left(\chi^{2}=103.212\right.$, significant at $1 \%$ level). The percentage of model's correct prediction is good (75.56\%). The Hosmer and Lemeshow test shows that the model adequately fits the data (the test was not significant at $5 \%$ level with $p$ value $=0.316$, thus, the null hypothesis could not be rejected). In general, the coefficients of most of the explanatory variables show the expected signs (Table 3 ) and confirm the tendency already discussed in Table 2 as regards to the factors which influence the most the adoption of cocoa agroforests. The rest of this section interprets the estimated coefficients and Odd Ratios $(\mathrm{OR})$ as well as the overall discussion of results with regards to each explanatory variable $\mathrm{X}_{1}$ to $\mathrm{X}_{14}$.

The coefficient of the age variable $\left(X_{1}\right)$ is significant at $5 \%$ level and its negative sign indicates that, the old farmers are less favourable to the adoption of cocoa agroforests as compared to the young category of farmers. The OR of this variable is 0.955 (lower than one) which implies that, for each additional year in the age of the farmer, the odds of adopting the cocoa agroforests decrease by $1-0.955=4.5 \%$ (Table 3 ). As a matter of fact, young farmers are mostly educated people who spent several years at school where they learned the advantages and benefits of different agroforestry techniques. This is in contrast with old farmers from the previous generations who are mainly illiterate people with a little knowledge in the practice of cocoa agroforests. Besides, the aged people are physically weak whereas the young farmers are strong enough thus are more powerful to carry or manage heavy and voluminous/bulky fruits harvested from the agroforests. Most old farmers are sick when they climb up into trees in order to pick up the fruits resulting from agroforests whereas young people are most of the time healthy to do such job. The old farmers rather prefer to cultivate the cocoa in mono-crop, which is a farming system inherited from their parents. We therefore recommend to the government to implement or subsidize the health insurance (currently inexistent) to cover the various risks for aged farmers who are more vulnerable to diseases from working around the forest areas. Our results corroborate with the previous findings by Jaza et al. (2015) according to which, young people are more favourable to the adoption of cocoa agroforests because 
they are more ambitious or courageous, and like adventurous situations such as the discovery of new techniques such as agroforestry. Other studies conducted by Jagoret et al. (2008) and Eboutou (2010) in the same area also show that, old generations still doubt on the efficacy and advantages of agroforestry whereas young people are interested to invest in this practice because they are convinced about its productivity.

Table 3 - Coefficients $(\beta)$ and odds ratio $[\operatorname{Exp}(\beta)]$ estimated from the logit model of adoption of cocoa agroforests by farmers in the Centre region $(\mathrm{N}=128)$

\begin{tabular}{llc}
\hline \multicolumn{1}{c}{ Explanatory variables } & \multicolumn{1}{c}{$\operatorname{Exp}(\beta)$} \\
\hline Age of farmer (in years) & $-0.045^{* *}$ & 0.955 \\
Gender of farmer (1/0) & $0.567^{* * *}$ & 1.763 \\
Farm size/land area cultivated by farmer (in ha) & $-0.028^{*}$ & 0.972 \\
Farmer's membership in a peasant's association (1/0) & $0.066^{* *}$ & 1.068 \\
Farmer's membership in a rural credit system (1/0) & $0.044^{*}$ & 1.044 \\
Frequency of contact with extension agents (per year) & $0.019^{*}$ & 1.019 \\
Level of education of farmers (1/0) & $0.758^{* *}$ & 2.134 \\
Ownership of land property right (1/0) & $-0.0198^{*}$ & 0.980 \\
Use of salarial labour (1/0) & $0.0354^{*}$ & 1.036 \\
Practice of crops' association or rotation (1/0) & $0.201^{*}$ & 1.222 \\
Occupation of managerial position (1/0) & $1.012^{* *}$ & 2.751 \\
Size of the farmer's household (in number of persons) & $0.370^{* * *}$ & 1.448 \\
Age of cocoa orchard (years) & $-0.016^{*}$ & 0.984 \\
Cocoa yield during previous years (t/ha) & $-0.0386^{* * *}$ & 0.962 \\
\hline
\end{tabular}

***: Significant at 1\%**: Significant at $5 \%$ *: Significant at $10 \%$

-2 Log likelihood $=136.218$ Nagelkerke $R^{2}=0.523$ Percentage of correct prediction $=75.56 \%$

Omnibus Test of Model Coefficients: $\chi^{2}=103.212^{* * *}$ Hosmer and Lemeshow Test: $\chi^{2}=9.065$

The gender variable $\left(X_{2}\right)$ has a positive coefficient (significant at $1 \%$ level) which implies that, male farmers are more likely to adopt the cocoa agroforests as compared to female farmers. For this variable, the model suggests an OR of 1.763 (greater than one) which indicates that, a change in the gender of farmer (from female to male) increases the odds of adopting the cocoa agroforests by a factor of 1.763 (Table 3). According to Eboutou (2010) and Jagoret et al. (2008), men are physically strong enough thus are more powerful to carry or manage heavy and voluminous/bulky fruits harvested from the agroforests. Besides, the fact that the male farmers of this region are taller (1.79 meters on average) than female (1.58 meters on average) is advantageous to men who can easily climb up in order to pick up the fruits from trees especially during the harvesting period of cocoa, safout, bush mango, ndjansang, etc (Jaza et al., 2015). Because of their small height associated to their weakness, the women in contrary prefer to grow the food crops/vegetables (e.g. maize, beans, onion, cabbage, tomatoes, etc) which are less voluminous, light to carry and easy to manage/harvest. Traditionally in the Centre region, the men are generally in charge of cultivating the cash crops which are hard in workload and provide high returns whereas the food crops/vegetables are more convenient to women because they are less labour demanding and less profitable. We therefore recommend to the government to grant subsidy or prize to female farmers who wish to invest in agroforestry. The subsidy could help this group of farmers to recruit male persons who could help them in the forests during the intensive hard work periods.

The farm size variable $\left(X_{3}\right)$ has a significant coefficient (at $10 \%$ level) with negative sign which indicates that, farmers with large land area are less likely to adopt the cocoa agroforests as compared to farmers with small parcels of land. The OR for this variable is 0.972 (lower than one) implying that, for each additional hectare of land area cultivated by a farmer, the odds of adopting the cocoa agroforests decrease by $1-0.972=2.8 \%$ (Table 3 ). In the field, the majority of reticent farmers to agroforestry own large land areas which they inherited from their parents. This group of farmers is already familiar for cultivating the cocoa in mono-crop rather than growing it in association with other domestic fruit trees. The agroforestry practice which is new for most of them is firstly tested in small parcels of land. They prefer to avoid risk by using big parcels of land for implementing the cocoa agroforests which they still doubt on its productivity/returns. It is after they realize its high productivity and efficacy that they extend its use in large land areas (Jagoret et al., 2008). 
The coefficient of farmer's membership in a peasant's association $\left(X_{4}\right)$ is significant (at $5 \%$ level) with positive sign, indicating that farmers belonging to a peasant's association are more likely of adopting the cocoa agroforests than those farmers without adherence to any group. In other terms, the odds of farmers who are members in a peasant's association are $1.068-1=6.8 \%$ higher than the odds of farmers who are non-adherents to any group (Table 3 ). In reality, a new member/farmer who adheres into a peasant association would meet the other colleagues who already practiced the cocoa agroforests' activities. Furthermore, the integration into a peasant association would help the farmers to address the transportation issues of the bulky fruits, trees, woods and other species harvested in the forests, thus facilitate the group problem-solving. This could reduce the high production costs highlighted by reticent farmers as main reason for not adopting the agroforestry technique (Jaza et al., 2015).

The farmer's membership in a rural credit system $\left(X_{5}\right)$ has a significant (at $10 \%$ level) positive coefficient which indicates that, farmers who are member in a rural credit system are more likely to adopt the cocoa agroforests than those farmers who are not affiliated into a banking system. More explicitly, the predicted odds for farmers who are member in a rural credit system are 1.044 times the odds for farmers who are non-members in a rural credit system (Table 3). As a matter of fact, a farmer who is customer of a bank has a great chance of borrowing money from its bank at a low interest rate. The credit could easily help him to compensate the investment cost and maintenance charges of the cocoa agroforests (Todem, 2005).

The coefficient for the frequency of contact with extension agents $\left(X_{6}\right)$ is significant at $5 \%$ level and its positive sign indicates that, the farmers with high frequency of contact with extension agents are more favourable to adopt the cocoa agroforests as compared those farmers who do not regularly meet the extension agents. The variable's OR of 1.019 proves that, for each additional contact of a farmer with an extension agent, the chances/odds that this farmer would adopt the cocoa agroforests increase by $1.019-1=1.9 \%$ (Table 3 ). As a matter of fact, an extension agent is the most suitable technician to convince a farmer for cultivating the cocoa agroforests in replacement of the cocoa produced in mono-crop. This advertisement is important to change the mind of reticent farmers so that they could better understand the efficacy, productivity, sustainable/long term effect of practicing the cocoa agroforests (Degrande et al., 2007). We therefore encourage the extension team of the country's Ministry of Agriculture to continue its sensitization work in conjunction with ICRAF/WAC so as to favour the adoption of cocoa agroforests by many farmers.

The computed coefficient of farmers' education $\left(X_{7}\right)$ indicate that, the educated farmers are more likely (at $5 \%$ significance level) of adopting the cocoa agroforests, as compared to the non-educated farmers. From the computed OR, enrolling a farmer into a school changes its status from illiterate to literate and increases the odds of adopting the cocoa agroforests by a factor of 2.134 (Table 3). The literate farmers better understand the numerous ecological gains from associating fruits' trees to cocoa (e.g. cocoa trees' protection against high storm, wind, and shade provision, soil fertility improvement, ground protection from heating, conservation of biodiversity of several flora and fauna species, etc) (Mbile et al., 2007). The enrolment at school could help reticent/illiterate farmers to learn these advantages or agronomic benefits of adopting the agroforestry. We therefore recommend the government to multiply the occasional trainings offered to farmers and reform the contents of academic curricula so as to include agroforestry related topics at primary or secondary schools.

The variable of farmer's ownership of land property right $\left(X_{8}\right)$ has a negative coefficient (significant at $10 \%$ level) which implies that, farmers owners of their land are less likely to adopt the cocoa agroforests as compared to those farmers who are land renters. The OR of 0.980 (lower than one) for this variable indicates that, a change in the ownership of land property right (from land renters to land owners) decreases the odds of adopting the cocoa agroforests by a factor of $1-0.980=2 \%$ (Table 3 ). From the previous literature (Todem, 2005; Mbile et al., 2007; Eboutou, 2010), about 75\% of farmers in the Centre region are cocoa cultivators and native persons who inherited their land from their parent. The local customs and traditions of the region forbid any inhabitant to sell an inherited parcel of land. Parcels for sales are therefore very rare so that people wishing to invest in cocoa agroforests would lack land to do so. Only those farmers who have the possibility to rent the land could invest on this 
activity. The land owners generally cultivate the cocoa as mono-crop, a practice which they inherited from their parents (Jaza et al., 2015). Unfortunately, the mono-crop system leads to the loss of soil fertility over time so that the land owners mainly have unproductive land. The land renters in contrary are more favourable to use their land for agroforestry, a practice with enhance the soil maintenance and fertility. Hence, the government should reform the law on land ownership in the region so as to enable non-native farmers to easily purchase land in order to engage into agroforest activities.

The variable of use of salarial labour $\left(X_{9}\right)$ has a positive coefficient (significant at $10 \%$ level) which implies that, farmers using salarial labour are more likely to adopt the cocoa agroforests as compared to the category of farmers employing non-salarial/familial labour. The OR of 1.036 for this variable implies that, for each additional use of salarial labour, the chances/odds that this farmer would adopt the cocoa agroforests increase by $1.036-1=3.6 \%$ (Table 3). As a matter of fact, working in the forest in general and harvesting the cocoa and other associated fruit species (e.g. safout, ndjansang, bush mango, etc) is a quite difficult task because it takes a lot of time and needs many people to do the work. The high weight of fruits, woods, trees, etc found in the agroforests obliges the farmers to recruit the salarial labour in order to be sure to finish the harvesting work on time. Unfortunately, with the rural exodus estimated at a $6.9 \%$ rate per year in the Centre region, the salarial labour becomes scarce so that the fruits and products sometimes perish in forest at the time of harvests because of the lack of young people to do the work (Jagoret et al., 2006). We therefore recommend the government to solve the rural exodus problem which would enable most young farmers to stay in the villages (rather than migrating to the cities) in order to work in the agroforests.

The variable of practice of crops' association or rotation $\left(X_{10}\right)$ has a positive coefficient (significant at $10 \%$ level) which implies that, farmers who previously practice crops' association or rotation are more likely to adopt the cocoa agroforests as compared to those farmers practicing cocoa in mono-crop. The model suggests an OR of 1.222 which indicates that, a change in the cropping system (from mono-crop to crop association/rotation) increases the odds of adopting the cocoa agroforests by a factor of 1.222 (Table 3). According to Jagoret et al. (2008) and Degrande et al. (2007), farmers who previously practice the mono-crop of cocoa would need a huge amount of money to invest in the new practice of cocoa agroforests whereas those who previously practice crops' association or rotation already own several inputs and domestic trees necessary to implement an agroforest (so there is no need to purchase new inputs and plant seedlings for this latter category of farmers). On the other hand, the farmers who previously practice crops' association/rotation better understand the benefits of preserving these domestic fruit trees on the protection of cocoa from sunshine. (e.g. trees provide shade necessary to combat the heat stress of cocoa). However, those farmers who never practice crop association or rotation do not know the advantages of that technique and consequently would have the tendency of continuing with the system of cocoa mono-crop rather than cocoa agroforests.

The occupation of managerial position $\left(X_{11}\right)$ has a positive coefficient (significant at $5 \%$ level) which implies that, farmers occupying a managerial position are more likely to adopt the cocoa agroforests as compared to those farmers without any responsibility position. More explicitly, an appointment of a farmer at any leading position increases the odds of adopting the cocoa agroforests by a factor of 2.751 (Table 3). As a matter of fact, a farmer occupying a managerial position is generally the first person to whom are passed new messages/informations to be disseminated to members of his group. He is the responsible person to decide on the behalf of the group he represents during the international or national meetings, seminars, workshops, etc. Attending those meetings is important for acquiring new knowledge and experience to be shared with other colleagues to whom he will explain the advantages of cocoa agroforests (Jaza et al., 2015). Hence, the government policy should favour the appointment of several farmers at the positions of responsibility so as to favour the agroforests adoption.

The coefficient for size of farmer's household $\left(X_{12}\right)$ is significant at $1 \%$ level and its positive sign indicates that, farmers with large household size are more favourable to adopt the cocoa agroforests as compared to those with small household size. The OR of this variable is 1.448 (greater than one) which implies that, for each additional person in the size of 
a farmer's household, the odds of adopting the cocoa agroforests by this farmer increase by 1.448 (Table 3). From the field experience, the work is rapidly done in households with large size. We already mentioned the bulky nature of items processed in agroforests (e.g. carrying fruits, trees, woods, branches, stems, etc), requiring a lot of people to work, especially during the harvesting periods. We therefore understand why men with polygamous marital status (with at least two wives) adopt easily the cocoa agroforests. The large number of children born from polygamous facilitates the hard work during the intensive harvesting periods (Degrande et al., 2007).

The coefficient for age of cocoa orchard $\left(X_{13}\right)$ is significant at $10 \%$ level and its negative sign indicates that, farmers with old cocoa orchard are less favourable to cocoa agroforests' adoption as compared to those with young cocoa orchard. The OR of this variable is 0.945 (lower than one) which implies that, for each additional year in the age of cocoa orchard cultivated by a farmer, the odds of adopting the cocoa agroforests by this farmer decrease by $1-0.945=5.5 \%$ (Table 3 ). As a matter of fact, the old cocoa orchards belong most of the time to aged farmers from previous generations, mainly to the illiterate persons, reticent to changes, with parcels of land containing cocoa orchards inherited from parents. In contrary, young cocoa orchards belong mostly to educated young farmers who better understand the advantages of cultivating the cocoa in association with domestic fruit trees (e.g. shade provision/protection of cocoa from the sunshine, heat stress, etc) (Jaza et al., 2010).

The coefficient for cocoa yield during previous years $\left(X_{14}\right)$ is significant at $1 \%$ level and its negative sign indicates that, farmers with low cocoa yield during the previous years are more favourable to adopt the cocoa agroforests as compared to those who recorded high cocoa harvest during previous years. The variable's OR of 0.962 (lower than one) indicates that, for each increase of one ton per hectare in the cocoa yield recorded by a farmer in previous years, the odds that this farmer adopts the cocoa agroforests decrease by 1$0.962=3.8 \%$ (Table 3 ). From the field experience, mainly farmers with low cocoa yield during the previous years are worried about their returns. This group of farmers would be willing to accept the innovation i.e. changing their farming system from the cocoa mono-crop to the cocoa agroforests which could increase their returns. They hope to improve their revenues by growing cocoa in association with other domestic fruits' trees such as safout, ndjansang, bush mango, etc. In contrary, farmers with high cocoa yield during the previous years prefer to continue the cultivation of cocoa in mono-crop, a system which they think is gainful; so it would be difficult to convince this latter group of farmers to change such a mono-crop system (Ministry of Agriculture, 2015).

\section{CONCLUSION}

Since the Cameroon's independence in 1960, farmers in the Centre region were used to produce cocoa in mono-crop thanks to the subsidy provided by the government during that period in order to support the production of this cash crop. In 1996, a program of domestication of fruit trees' species cultivated in association to cocoa was launched by ICRAF/WAC; but its adoption rate remains very low (about $29 \%$ ) because farmers are not yet convinced on its profitability. This paper analyzes the various socio-economic factors which prevent the adoption of cocoa agroforests by reticent farmers.

The descriptive results reveal that, farmers adopting the cocoa agroforests are mostly young, male, member of peasant association, member in rural credit system, frequently in contact with extension agents, educated, land renters, employers of salarial labour, occupants of managerial positions, with large household size, with previous practice of crops' association or rotation and with low cocoa harvest during the previous years. However, the likelihood is low to adopt the cocoa agroforests for those old farmers, owners of large land area, and with old cocoa orchard. The computed odds ratios from the logit model also confirm these trends.

In short, in order to favour the adoption of cocoa agroforests by large number of farmers, the study recommends to the government authorities to consider rewarding female farmers and implementing a health insurance system for aged farmers. Its policy should also promote peasants' association to address the transportation issues, intensify the extension programs to convince the reticent farmers on the benefits of cocoa agroforests, reform the contents of 
academic curricula so as to include agroforestry related topics, set up an efficient credit system for farmers willing to engage in cocoa agroforests, discourage the cultivation of cocoa in mono-crop and encourage the association of cocoa to other domestic trees, appoint farmers at managerial positions, encourage polygamous union, renew the cocoa orchard, etc. A land reform is also necessary so as to give the possibility to non-native people to engage in cocoa agroforest activities in this ares. This could prevent rural exodus and give the possibility for young farmers to stay in villages and invest in cocoa agroforests.

\section{ACKNOWLEDGEMENTS}

The author wishes to thank the Alexander von Humboldt (AvH) Foundation in Germany for funding this research.

\section{REFERENCES}

1. Degrande A., Essomba H., Bikoué-Mekongo C.A. and Kamga A. 2007. Domestication, genre et vulnérabilité. Participation des femmes, des jeunes, et des catégories les plus pauvres à la domestication des arbres agroforestiers au Cameroun. Working Paper $\mathrm{N}^{\circ} 48$. ICRAF/WAC, Yaoundé, Cameroon.

2. Eboutou, L.Y. 2010. Rentabilité financière des agroforêts à base de cacao enrichies par des arbres domestiqués: cas du bassin de production du Centre-Sud au Cameroun. Mémoire de Fin d'Etudes. Faculté d'Agronomie et des Sciences Agricoles, Université de Dschang, Cameroun.

3. Gujarati, D.N. 1995. Basic econometrics (third edition). McGraw-Hill: New York, USA.

4. Jagoret P., Todem N.H., Bouambi E., Battini J.L. and Nyassé S. 2006. Caractérisation des systèmes de cacaoculture du Centre-Cameroun. IRAD/CIRAD. Yaoundé, Cameroun.

5. Jagoret P., Todem N.H., Bouambi E., Battini J.L. and Nyassé S. 2008. Diversification des exploitations agricoles à base de cacaoyer au Centre-Cameroun: Mythe ou Réalité? Biotechnol. Agron. Soc. Environ., 13 (2) 2: 271-280.

6. Jaza F.A.J, Eboutou L.Y., Degrande A., Moulende T.F., Kamajou F., and Bauer S. 2015. Benefits from trees' species diversification in cocoa agroforests at the Centre region of Cameroon. Russian Journal of Agricultural and Socio-Economic Sciences, RJOAS 11(47):3-11, November 2015.

7. Mbile P., Tsobeng A. and Degrande A. 2007. Intégration et gestion des arbres dans les champs. Manuel d'Aide à la Décision. ICRAF, Yaoundé, Cameroun.

8. Ministry of Agriculture 2015. Annuaire des statistiques du secteur agricole, campagne 2014/2015. Division des Etudes et Projets Agricoles, Cellule des Enquêtes et Statistiques, Yaoundé, Cameroun.

9. Terrell, G.R. 1999. Mathematical statistics: a unified introduction. Springer-Verlag: New York, USA.

10. Todem, N.H. 2005. Bilan financier des systèmes de cacaoculture du Centre-Cameroun. Mémoire de Fin d'Etudes. Faculté d'Agronomie et des Sciences Agricoles, Université de Dschang, Cameroun.

11. Wooldridge, J.M. 2009. Introductory econometrics: a modern approach. McGraw-Hill: New York, USA. 